\title{
TEACHING LISTENING TO JUNIOR HIGH SCHOOL STUDENTS USING “GUIDED METACOGNITIVE SEQUENCE"
}

\author{
Tuty Mujiatin \\ Magister Pendidikan Bahasa dan Sastra Inggris, UNESA \\ (tutymujiatin@gmail.com)
}

\begin{abstract}
Abstrak
Penelitian ini menguji apakah penggunaan pengajaran strategi metakognitif berdasarkan "Tahapan Metakognitif Terbimbing" dapat meningkatkan kemampuan siswa dalam mendengarkan pelajaran bahasa Inggris yang menitikberatkan pada tiga indikator: menentukan informasi tersurat, menentukan informasi tersirat, dan menentukan gambaran umum. Penelitian ini menerapkan desain penelitian praeksperimen tes awal dan tes akhir dengan grup tunggal. Sejumlah 32 siswa kelas 8 SMP Negeri 2 Ponorogo dipilih sebagai peserta grup. Grup ini memperoleh 5 (lima) sesi pertemuan pelajaran mendengarkan teks recount di kelas dengan menerapkan pengajaran strategi metakognitif berdasarkan "Tahapan Metakognitif Terbimbing". Data nilai siswa pada tes awal dan tes akhir dianalisa menggunakan uji t sampel berpasangan dengan tingkat signifikansi 0,05 $(p<0.05)$ untuk menguji peningkatan skor. Hasil penelitian menunjukkan nilai tes akhir siswa lebih tinggi secara signifikan dibanding nilai awal (72,41dibanding $61,06, p=0,000, p<0,05)$. Hasil ini menunjukkan bahwa penggunaan pengajaran ini memacu peningkatan pemahaman siswa dalam mendengarkan. Hasil ini menuntut perlunya menggabungkan pengajaran ini ke dalam program pengajaran mendengarkan sehari-hari di kelas untuk membantu siswa mengatasi kesulitannya dalam mendengarkan Bahasa Inggris.
\end{abstract}

Kata kunci: tahapan metacognitif terbimbing, informasi tersurat, informasi tersirat, gambaran umum

\section{A. INTRODUCTION}

Listening comprehension skill is an important foreign language learners' skill in oral communication. Over 50 percent of the time that students spend functioning in a foreign language was devoted to listening (Chen, 2011; Nunan, 2001). In the process of English learning, cultivation of listening comprehension competence should not be ignored since good listening comprehension may help students enhance their English knowledge and improve their communicative competence in English. 
In spite of its importance, it is arguably the least understood and most overlooked of the four skills (Listening, Speaking, Reading and Writing) in the language classroom (Nation \& Newton, 2009). Moreover, second and foreign language learners are also rarely taught how to listen effectively although they are aware of the importance of this skill (Vandergrift et al., 2006). In fact, in Indonesia listening has been almost ignored in both junior and high school, where students spend six years in English language learning. This results in poor listening performance. As compared with other language skill, listening has been considered the most challenging subject. Therefore, low scores in listening are inevitable. This has been made worst by teachers' opinion that listening comprehension requires no skill and in which the more one listens, the greater the listening comprehension competence (Chen, 2011).

In fact, however, listening is more than merely hearing words. Listening is an active process by which students receive, construct meaning from, and respond to spoken and or nonverbal messages. As such, it forms an integral part of the communication process and should not be separated from the other language arts (Emmert in Pekin, 2008). Likewise, Vandergrift (2006) asserted that listening is a complex, active process of interpretation in which listeners try to suit what they hear with their prior knowledge. According to Richard (2008) this process is more complex for second language learners who have limited memory capacity of the target language.

Therefore, it is necessary for them to utilize various listening strategies. The teachers' job then is to guide them in discovering important aspects of the listening process to help students understand mental and emotional processes in their learning. When students become aware of the nature and demands of listening to another language, they will be in a better position to evaluate and manage their own learning. Teaching that explicitly elicits and develops learners' knowledge about the listening process is in this study referred to as 'metacognitive instruction'.

Metacognition can be described as awareness of how one learns; awareness of when one does and does not understand; knowledge of how to 
use available information to achieve a goal; ability to judge the cognitive demands of a particular task; knowledge of what strategies to use for what purposes; and assessment of one's progress both during and after performance (Flavell, 1979). Similarly, Baker (2002, 2008) stated that metacognition refers to the knowledge and control that we have over our cognitive processes. Generally, metacognition includes awareness and control of planning, monitoring, repairing, revising, summarizing, and evaluating. Essentially, we learn awareness of our comprehension processing. More specifically, we learn strategies that support our comprehension (our awareness of strategies) and we learn how to carry out these strategies effectively (our control of strategies).

Based on Vandergrift's model and its variations, Goh (2010) described a set of integrated sequence-of-lesson procedures so called "Guided Metacognitive Sequence" that includes further planning activities and active modelling by teachers of some processes. This was an approach to incorporating listening strategies in a listening lesson that involves a cycle of activities (steps) consisting of five steps, i.e. Pre-listening activity, first listen, Pair process-based discussion, Second listen, and Whole-class process-based discussion.

The metacognitive listening sequence creates a lesson where learners are guided at specific stages to orchestrate metacognitive processes underlying successful listening. It integrates awareness-raising activities with normal listening input and comprehension activities that learners do in class. Each sequence of lessons isaimed at teaching learners how to use listening strategies through teacher scaffolding and modelling, peer collaboration, and individual practice. This procedure is based on the integrated pedagogical model for teaching listening. The model provides opportunities for learners to experience three verification phases of a text. In so doing, learners deepen their understanding of the content and become more familiar with the metacognitive processes involved. The model focuses on the use of the following strategies: planning, predicting, monitoring, evaluation, directed attention, selective 
attention, and problem solving. A key feature of this model is the structure it offers for guiding learners through collaborative learning activities. Learners who experience these activities may gradually increase their autonomy and control over their listening processes. Goh (2006) adapted Vandergrift's (2004) model to include peer dialogue in process-based discussions and personal evaluation at the reflection stage.

Based on Vandergrift's model and its variations, Goh (2010) describes a set of integrated sequence of lesson procedures that includes further planning activities and active modelling by teachers of some processes:

The five steps in "Guided Metacognitive Sequence" in a listening lesson (Goh, 2010) are as follows: Step 1 is Pre-listening activity: In pairs, students predict the possible words and phrases that they might hear. They write down their predictions. They may write some words in their first language. Step 2 is the First listening: As they are listening to the text, students underline or circle those words or phrases (including first-language equivalents) that they have predicted correctly. They also write down new information they hear. Step 3 is Pair process-based discussion: In pairs, students compare what they have understood so far and explain how they arrived at the understanding. They identify the parts that caused confusion and disagreement and make a note of the parts of the text that will require special attention in the second listen. Step 4 is the Second listening: Students listen to those parts that have caused confusion or disagreement areas and make notes of any new information they hear. Step 5 is the whole-class process-based discussion: The teacher leads a discussion to confirm comprehension before discussing with students the strategies that they reported using. Students ended the sequence by evaluating the listening lesson and wrote about their perceptions of the task and views on insights gained from the discussion.

Despite recognizing the importance of listening strategies for the development of foreign language proficiency, very limited studies on the metacognitive strategies in relation to listening comprehensionhave been conducted in Indonesia. Therefore, it is urgent to examine how metacognitive 
strategy instruction in this term the instruction based on "Guided Metacognitive Sequence" can be implemented in Indonesian classroom. Specifically this study seeks the answers to the following questions: Is there any significant difference in the scores of listening comprehension test before and after the junior high school students are taught by using metacognitive strategies instruction based on "Guided Metacognitive Sequence"? The scores are specifically for the indicators of listening skill of "Standar Kompetensi Lulusan" for Junior High School 2006. They are determining explicit and implicit information and recognizing main points of the listening text.

The study employs pre experimental research design with one group, pretest-posttest design (Ary et al., 2010). Using Cohen et al.'s (2007: 282) perspectives, this pre experimental design also belongs to quasi experimental research. This is because it lacks control over the randomization of exposures/groups. Using this design, the study has little power to establish causation between the independent variable (strategy instruction based on "Guided Metacognitive Sequence") and the dependent variable (students' scores in listening comprehension test focusing on recognizing main points, determining explicit information, and determining implicit information of the listening text).

The design was chosen based on the consideration about the time constraints for completing the study. It also helped the researcher more focus on the instruction process. Therefore it did not include a control group. Only one group was exposed to the presence of the experimental treatment: students of grade 8D SMP Negeri 2 Ponorogo in the academic year 2013-2014 which consists of 32 students. The group was selected because based on the preliminary study conducting at the beginning of the academic year; the students in this class had the lowest mean score in the formative and midterm listening test.

The post test was delayed until one month. The researcher and Mrs. HN as the English teacher of the group carried out team teaching to the 
experimental group. The intervention program was conducted during five meetings beginning from the first week till the third week of October 2013.

Before starting the intervention, preparatory lessons (one meeting equals with 80 minutes at total) were carried out in order to inform students generally about metacognition. During preparatory classes, students were provided with information about metacognition in accordance with their levels.

The next meeting after the preparatory lesson, the students did pre test. In the following five meetings, the intervention programs were conducted. The duration of each meeting was 80 minutes. Each meeting applied lesson plan containing metacognitive strategy instruction based on "Guided Metacognitive Sequence".

The materials used during the treatment were recount texts for grade 8 taken from Electronic School Book or Buku Sekolah Elektronik (BSE) published by Ministry of Education and from internet websites. One week after the last meeting of the instruction, the post test was carried out.

The instruction process of the implementation of "Guided Metacognitive Sequence" in listening was started from the preparatory class. It informed the students about everything related to the metacognitive strategy instruction in listening. The teachers distributed copies of types of metacognitive listening strategy. A brief explanation about the lesson plan and what they were going to do in the next listening lessons were also given.

In the first meeting, the pre listening activities reviewed the strategy. Then, brainstorming session and discussion questions related to the instruction and the topic were conducted. In this case, metacognitive strategy types which were elaborated were planning and monitoring. Planning happened when the teachers explain the objective of the lesson and the instruction used. Monitoring occurs when students check and verify their understanding during brainstorming session and discussion question.

Before listening exercises and listening guide (Appendix 2) were distributed, the students were provided with necessary background information and new vocabularies needed. The students were asked to read questions 
carefully and the teachers encouraged them to ask when they don't understand the questions.

Then, students predict the possible words and phrases that they might hear (listening guide number 1). This is the guide that generated students' prediction to help them to use real expectation about what the speaker were going to say and what might happen. It also provided the necessary context for the specified listening task. The prediction can be in Indonesian. Planning and directed attention were elaborated here. Planning took place because the students haven't dealt with the audio. The process also applied directed attention since the students decided to attend in general to the listening text they would hear.

In whilst-listening activities, participants prepared for taking note and then listen to the audio (first listen). While listening, they marked correct words or phrases that they have predicted before (listening guide number 2). They also wrote new information. Following this, in pairs the participants compared their understanding about the audio they heard. While looking at the exercises, they made notes parts of the listening text that required special attention. Since students decided to listen to detail information of the listening text, selective attention activities occurs. It also involved monitoring and evaluation strategy when the participants practiced note taking. They checked and corrected their understanding about the task.

In second listening, the participants listened again and made notes to check their understanding. They paid much attention to those parts that caused confusion (listening guide number 4). This time, they began to answer the questions. The teachers guided them since the answers were open ended and constructing sentences needed good writing skill. The metacognitive processes involved were selective attention, monitoring, evaluation, and problem solving because they came to specific information to confirm their understanding and to answer the problems.

In post listening activities, participants listened to the third time. They reviewed their notes and rechecked their answer. Again, metacognitive aspects 
such as selective attention, monitoring, evaluation, and problem solving took place since they wrote any information needed to answer the questions. A whole class discussion was conducted. Teachers also supplied the right answers (listening guide number 5). Right after this, the teachers gave models on how to use kinds of metacognitive strategies in listening and discussed with students the strategies they used.

As reflection, the participants filled in the post listening evaluation checklist (Appendix 3). The participants were also asked to write simple notes on how they completed the listening tasks. Teachers guided them by asking questions: what do you think about the lesson today? what problems do you have so far? And so on. Some students were asked to read their notes and others gave comments. The followings are some of students' reflection notes concerning their comments on the new strategy and their problems encountered during the program:

I like this lesson. This is different

I like this lesson. I know my problems in listening

Making prediction is difficult. I must focus I can't guess. I don't know many vocabularies stated. I must concentrate

The text is too long, I miss many points

The reading is so fast. I'm not sure about the answer

I'm not sure about the answer. When answering subjective test, I have to pay much attention and really listen

It's very noisy outside, I don't understand the passage.

The teacher's voice was clearer. But listening to audio is important.

The same instruction processes with different listening texts and tasks (Appendix 1a-1e) were carried out till the last meeting of the experimental treatment program.

The instrument needed to collect the data was listening test. It was a researcher-made test used to measure the listening comprehension of the group. It only needed one test both for pre test and post test. 
Table 1. List of test numbers related to the sub skills/indicators

\begin{tabular}{|l|l|l|}
\hline No & Sub skill/indicator & Numbers \\
\hline 1. & $\begin{array}{l}\text { Determining explicit information of the } \\
\text { listening text }\end{array}$ & $\begin{array}{l}1,4,7,10,13 \\
\text { listening text }\end{array}$ \\
\hline 2. & Recermining implicit information of the & $2,5,8,11,14$ \\
\hline 3. & Recognizing main points of the listening text & $3,6,9,12,15$ \\
\hline
\end{tabular}

To administer the test to get the data both for pre test and post test, the test has been tried out. As Brown (2004) affirms, the most complex criterion of an effective test - and arguably the most important principle is validity. Consequently, before and after the try out was conducted the test underwent several kinds of evidence to support its validity:

a. Before the try out

Content validation is the extent to which the test accurately reflects the syllabus on which it is based. The purposes of content specification list to ensure that the test reflects all areas to be assessed in suitable proportion. As for that, the validation has been passed through. The test was observed in terms of its appropriacy with the Indonesian English curriculum 2006. To support its validity, the test outline was provided. Content validation related to the syllabus appropriacy has been judged by five teachers. The validation results informed that the test has been appropriate with the Indonesian English curriculum 2006.

b. After the try out

The try out was carried out on $30^{\text {th }}$ September 2013. After that, the data resulted from the try out was analyzed to measure the items against item discrimination (ID) as suggested by Brown (2004). Next, SPSS 16.0 was employed to see whether the test was valid (test and concurrent validity) and reliable in terms of statistical calculation. The findings can be seen as follows:

(1) Item Discrimination (ID) 
ID is the extent to which an item differentiates between high- and lowability test takers. A formula for calculating ID has been applied.

High discriminating power would approach a perfect 1.0. The formula indicates that items which have ID of below .50 should be revised. The data revealed that 7 numbers have ID of below .50. Therefore, those numbers were not used. Since there were only 15 numbers used for the study, the researcher selected three more numbers not to be utilized.

(2) Concurrent validity

Concurrent validity is a measure of how well a test correlates with a measure that has previously been validated. The concurrent validity is often quantified by the correlation coefficient between the two sets of measurements obtained for the same target subject. As for that, by applying SPSS 16.0, the researcher compared the data from the try out and the score of listening test previously obtained by the students of the group, in this case mid term test score. It revealed that the correlation coefficient was .78. The number informs that there is a large correlation between the two tests suggesting quite a strong relationship between them.

(3) Reliability test.

From the SPSS analysis, the reliability of the test was 0.68 . Test is determined to be reliable if the Cronbach's Alpha is more than 0.6.

\section{B. RESULTS AND DISCUSSION}

After the completion of the instruction program and the taking of the post test, the data have been analyzed to test the hypotheses. The analysis was to find out whether the metacognitive listening strategy training results a significant difference in the score of listening comprehension focusing on three indicators; recognizing main points of the listening text, determining explicit information, and determining implicit information of the listening text before and after the training. The scores obtained from the group were compared and statistically evaluated by applying paired-sample t-test available in SPSS 16.0 . 
From the SPSS analysis, conclusions have been drawn by seeing Sig (2Tailed) value or $\mathrm{p}$-value. The 0.05 level $(p<0.05)$ was used to determine any significant differences for all results.

The result on testing the hypotheses are as the following:

a. General hypothesis:

There is significant difference in the score of listening comprehension test before and after the junior high school students are taught by using metacognitive strategies instruction based on "Guided Metacognitive Sequence".

In order to reject $\mathrm{H} 0$ or accept $\mathrm{H} 1$, the pre- and post-test results of the group of students participating in the study were collected and compared. The analysis evaluated scores of all numbers without classifying numbers containing certain sub skills/indicators. So, it collected and compares the scores of the students derived from numbers 1 to 15 . As shown in Table 2 the students scored slightly higher in the post- test than in the pre-test $(72.41$ versus 61.06). This paired samples t-test (Table 3) indicates that the improvement in the post test was significant $(p=0.000)$. In this case Null hypothesis was rejected and the alternative hypothesis was accepted (Julie Pallant (2010).

Table 2. Mean scores of all numbers in the pre-test and post-test

\begin{tabular}{|l|l|l|l|l|l|}
\hline & & Mean & N & Std. Deviation & Std. Error Mean \\
\hline \multirow{2}{*}{ Pair 1 } & posttest & 72.41 & 32 & 7.107 & 1.256 \\
\cline { 2 - 6 } & Pretest & 61.06 & 32 & 5.858 & 1.036 \\
\hline
\end{tabular}

Table 3. Paired samples t-test of all numbers in the pre-test and post-test

\begin{tabular}{|c|c|c|c|c|c|c|c|c|c|c|}
\hline & & \multicolumn{7}{|c|}{ Paired Differences } & \multirow[b]{2}{*}{ Df } & \multirow[b]{2}{*}{$\begin{array}{l}\text { Sig. } \\
\text { tailed })\end{array}$} \\
\hline & & Mean & $\begin{array}{l}\text { Std. } \\
\text { Deviati } \\
\text { on }\end{array}$ & $\begin{array}{l}\text { Std. } \\
\text { Mean }\end{array}$ & Error & $\begin{array}{l}95 \% \\
\text { Interval } \\
\text { Difference }\end{array}$ & $\begin{array}{l}\text { Confidence } \\
\text { of the }\end{array}$ & $\mathrm{T}$ & & \\
\hline
\end{tabular}




\begin{tabular}{|l|l|l|l|l|l|l|l|l|l|}
\hline & & & & & Lower & Upper & & & \\
\hline Pair 1 & $\begin{array}{l}\text { posttest } \\
\text { pretest }\end{array}$ & -11.344 & 7.078 & 1.251 & 8.792 & 13.896 & 9.066 & 31 & .000 \\
\hline
\end{tabular}

b. Specific hypotheses

The specific hypotheses are classified into three sub skills. They are, determining explicit information, determining implicit information of the listening text, and recognizing main points of the listening text. Each sub skill was immersed in certain numbers in the test.

Covering three indicators all together, the students had a higher mean post test score than pre test score. The result also shows that there was statistically significant differences between the two scores $((p=0.000, p<0.05)$ in the three indicators (Table 4). Hence alternative hypothesis was received. The following is a list of students' mean scores in pre test and post test.

Table 4. Students' mean scores in pre test and post test

\begin{tabular}{|l|l|l|}
\hline Sub skills & Pre test & Post test \\
\hline All sub skills & 61.06 & 72.41 \\
\hline Determining explicit information & 75.00 & 88.12 \\
\hline Determining implicit information & 55.00 & 65.00 \\
\hline Recognizing main points & 53.12 & 64.38 \\
\hline
\end{tabular}

Based on the testing of the hypotheses, the results can be drawn. The answer to the general question is "There is significant difference in the score of listening comprehension test before and after the junior high school students were taught by using metacognitive strategies instruction based on "Guided Metacognitive Sequence"'. The results informed that in the post test the students' mean score improved. The difference condition of means (pre test and post test) has been significance telling that the instruction program to the group may have given considerable effect.

The answers to the three specific research questions are: 
1. There is a significant difference in the score of listening comprehension test focusing on determining explicit information of the listening texts before and after the junior high school students were taught by using metacognitive strategies instruction based on "Guided Metacognitive Sequence".

The t-test results in Chapter 3 showed that concerning scores in determining explicit information of the listening text, the students had a higher mean post test score than pre test score (88.12 versus 75.00$)$. The result also showed that the difference was statistically significant $((p=0.000$, $p<0.05)$.

The mean scores indicated that the students performed better in the post test. The 0.05 level $(p<0.05)$ was used to determine any significant differences between the two scores. The analysis told that the $p$ value reached 0.000. It can be said that there is statistically significant difference between the two tests (pre test and post test) and that the differences are probably due to the effect of the treatment program, not other possible factors.

2. There is a significant difference in the score of listening comprehension test focusing on determining implicit information of the listening texts before and after the junior high school students are taught by using metacognitive strategies instruction based on "Guided Metacognitive Sequence".

The answer has been based on the results of the t-test analysis. The result demonstrated that the students outperformed in the post test on determining implicit information (the mean was 65.00 versus 55.00). The mean score of post test was significantly different from the $\operatorname{pre} \operatorname{test}(p=0.000, p<0.05)$.

The results informed that regarding this sub skill, the students' post test score was higher than in the pre test. The $p$ value of 0.000 suggested that the difference between conditions of Means was significance and it might be due to the effect of the experimental teaching program.

3. There is a significant difference in the score of listening comprehension test focusing on recognizing main points of the listening texts before and after the 
junior high school students are taught by using metacognitive strategies instruction based on "Guided Metacognitive Sequence".

The statistical analysis concerning this sub skill told that in the post-test, the students made greater progress after the pre-test (53.12 versus 64.38$)$. The $t$ test also showed significant results $(\mathrm{p}=.000)$.

The results reported that the mean score of students' post test relating to recognizing main points of the listening text increased. Since the $p$ value was 0.000 , the difference between the pre and post test mean score became significance. The significance result provides evidence that the progress in the post test occurs might be because of the implementation of the experimental treatment to the group, not because of other reasons.

To sum up, the results tells that the average scores of post test show an overall higher performance of the students. There is statistically significant difference between the pre test and post test in all sub skills. These findings can be justified on the basis of the effectiveness of the metacognitive strategy instruction practiced by the group.

The students' achievement was the highest on determining explicit information (88.12). The strategy emphasized the student-spoken text relationship, where the students explore the text and also the class discussion that stimulated exchanging information between them. Practicing note taking strategy contributed positively to students' achievement on determining explicit information.

The mean score on recognizing main points were the lowest. This sub skill requires more practice. Directed attention and problem solving played important factors to cope with this indicator.

In determining implicit information of the spoken text, improvement was relatively high (64.38 versus 53.12). The activities concerning the indicator practiced the students to predict and guess any possible words that might appear. Brainstorming session and discussion questions in planning stage played significant role to deal with this skill. 


\section{CONCLUSION}

Based on the results of the research, it can be concluded that metacognitive strategy instruction based on "Guided Metacognitive Sequence" increases students' listening comprehension focusing on three indicators: determining explicit information, determining implicit information, and recognizing main points of the listening text. Due to this fact, metacognition can be used as a useful tool in order to develop the strategy and knowledge of how to overcome the students' listening difficulties.

Language learners need to be guided and supported in their efforts to achieve success. The main aim of the instruction in "Guided Metacognitive Sequence" is to teach students how to listen as this knowledge is probably what is lacking in most students who find listening in EFL a challenge. By encouraging the learners to engage in metacognitive strategies of planning, monitoring and evaluating, learners no longer became passive recipients of instruction, instead, the responsibility for learning moved from the teacher to the students. Using "Guided Metacognitive Sequence" in the listening class not only provides the students with the knowledge and control over their listening process, but it also enhances their motivation (Vandergrift, 2002).

Although this study shows on the usefulness of metacognitive strategy training in listening classes, the findings cannot be generalized to all classroom in EFL context in Indonesia since the number of subjects, the duration of the instruction, and different variables can change the result of such studies.

Furthermore, it should be noted that the present study has at least two limitations that should be acknowledged. The study lacked a control group. In experimental studies, a control group can determine if the effects of the treatment has, in fact, resulted from the treatment rather than other possible factors. Another limitation of the current research was the similarity of the preand post-tests. Due to this condition, though there was one month distance between the two tests, the students could have learned from the pre-test and 
this could have affected their scores in the post-test. In other words, practice effect has become factor that influences the students' improvement.

Reflecting on the findings and on the usefulness of the strategy, some suggestions have been addressed to some parties. First is to English teacher. Hopefully it can convince them to be more responsive of the benefits of metacognitive strategy instruction and include this strategy in their lessons. Students need to be made aware and should be informed of the importance of metacognitive strategies. It is the teacher's responsibility to raise the students' awareness of metacognitive strategy use and provide them with the opportunity to use metacognitive strategies in appropriate contexts. They should make every attempt to help students develop this strategy. First, teachers should teach what metacognition is and what role metacognition plays in learning. This helps listeners to have a comprehensive knowledge about listening tasks and listening strategies that may facilitate or impede listening. Second, instructors should carry out activities where listeners are given opportunities to practice metacognitive strategies.

Second is for Course book writers. They should include this strategy in their course book so as to increase teachers and students' awareness of the advantage of the strategy. Thus, it encourages them to implement it effectively and regularly throughout classroom teaching.

For future researchers, it is hoped that this study will elicit more research exploring the role of different strategy instructions on students' performance in different language skills. In addition, further study with a control group is necessary. Future research should involve a larger participant to ensure generalizability of the study.

The complete and thorough validation process: content, face, and construct validation of the test are also important aspects that should be considered much better in upcoming research. 


\section{REFERENCES}

Alfian. (2011). Language Learning Strategies of High School Students. Media Akademika, 26(1).

Anderson, A., \& Lynch, T. (1988). Listening. Oxford: Oxford University Press.

Anderson, N. J. (1991). Individual differences in strategy use in second language reading and testing. Modern Language Journal, 75, 460-472.

Ary, D., Jacobs, L. C., Sorensen, C., \&Razavieh, A. (2010). Introduction to Research in Education (Eighth ed.). Belmont, CA: Wadsworth, Cengage Learning.

Bozorgian, Hossein, \&Alamdari, EbrahimFakhri. (2013). Metacognitive Instruction: Global and Local Shifts in Considering Listening Input. Education Research International, 2013, 1-8.

Brown, H. D. (2004). Language Assessment_Principles and Classroom Practices. New York: Pearson Education Limited.

Chamot, A. U. (2005). Language learning strategy instruction: current issues and research. Methodology in language teaching: An anthology of current practice. Cambridge: Cambridge University Press.

Chen, H. (2011). Brief Analysis of Strategies to Improve English Listening Comprehension Competence among Non-English Undergraduate Students. Asian Social Science, 7(12).

Cohen, L., Lawrence, M., \& Keith, M. (2007). Research Methods in Education. New York: Routledge.

Coskun, A. (2010). The Effect of Metacognitive Strategy Training on the Listening Performance of Beginner Students. Novitas-ROYAL (Research on Youth and Language), 4(I), 35-50.

Departemen Pendidikan Nasional. (2006) Kurikulum Tingkat Satuan Pendidikan (KTSP). Jakarta: Departemen Pendidikan Nasional.

Field, J. (2008). Listening in the Language Classroom. Cambridge: Cambridge University Press. 
Flavell, J. H. (1976 ). Metacognitive aspects of problem solving In L. B. Resnick. (ed.). The nature of intelligence (pp. 231-235). Hillsdale, NJ: Lawrence Erlbaum Associates.

Flavell, J. H. (1979). Metacognition and cognitive monitoring: A new area of cognitive-developmental inquiry. American Psychologist, 34, 906-911.

Goh, C. (1997 ). Metacognitive awareness and second language listeners. ELT Journal, 51(4), 361-369.

Goh, C. (2009). Metacognitive Instruction for Second Language Listening Development. Regional Language Centre Journal, 39(2), 188-213

Goh, C. (2010). Listening as process: Learning activities for self-appraisal and self-regulation. Retrieved from http://www.academia.edu/953241/8

Goh, C., \& Taib, Y. (2006). Metacognitive instruction in listening for young learners. ELT Journal 60(3), 222-232.

Haller, E. P., Child, D.A. \& Walberg, H.J. (1988). Can Comprehension be taught? A Quantitative Synthesis of "Metacognitive Studies." Educational Researcher, 17.9 pp 5-8. Educational Researcher, 17(9), 5-8.

Harmer, J. (2001). The Practice of English Language Teaching. Harlow: Pearson Education.

Hien, T. V. (2008). Difficulties and Strategies in Listening Comprehension. Retrieved from www.lhu.edu.vn/139/662/

Kavaliauskienè, G. (2008). Podcasting: A Tool For Improving Listening Skills. Retrieved from http://www.google.com/url?q=http://www.tewtjournal.org/ Littlewood. (1981). Communicative Language Teaching. Cambridge: Cambridge University Press.

Malik, F. A., Sarudin, I., Muhamad, A. J., \& Ibrahim, E. H. E. (2013). Effects of Metacognitive Listening Strategy Training on Listening Comprehension and Strategy Use of ESL Learners. World Applied Sciences Journal (Special Issue of Studies in Language Teaching and Learning), 21, 57-66.

Donough, J. M., \&Donough, S. M. (1997). Research Methods for English Language Teachers. London: Hodder Arnold. 
Nation, I.S.P, \& Newton, Jonathan. (2009). Teaching ESL/EFL Listening and Speaking. New York: Routledge, Taylor \& Francis.

Nunan, D. (2001). Listening in Language Learning-The Nature of Listening. Retrieved from http://soda.ustadistancia.edu.co/enlinea/SandraMilenaRodriguez_Listening /listening_comprehension_process.html

O'Malley, J. M., \& Chamot, A. U. (1990). Learning Strategies in Second Language Acquisition. Cambridge: Cambridge University Press.

O’Malley, J. M., Chamot, A. U., Stewner-Manzanares, G., Russo, R., \& Kupper, L. (1985). Learning strategy applications with students of English as a second language. TESOL Quarterly, 19, 285-296.

Oxford, R. L. (1989). Use of Language Learning Strategies: a Synthesis of Studies with Implications for Strategy Training. System, 17(2).

Pallant, J. (2011). SPSS SURVIVAL MANUAL : A step by step guide to data analysis using SPSS. Crows Nest, Allen \& Unwin.

Pekin, A. (2008). Listening Activities. Retrieved from http://www.ingilish.com/listening-activities.htm

Rasouli, M., Mollakhan, K., \&Karbalaei, A. (2013). The effect of metacognitive listening strategy training on listening comprehension in Iranian EFL context. European Online Journal of Natural and Social Sciences 2013, 2(1), 115-128.

Richards, J. C. (2008). Teaching Listening and Speaking From Theory to Practice. Cambridge: Cambridge University Press 2008.

Ridley, D. S., Schutz, P. A., Glanz, R. S., \& Weinstein, C. E. (1992). Selfregulated learning: the interactive influence of metacognitive awareness and goal-setting. Journal of Experimental Education, 60(4), 293-306.

Rivers, V. M. (1992). Communicating Naturally in a Second Language. Cambridge: Cambridge University Press.

Rost, M. (1994). Introducing listening. London: Penguin. 
Thompson, I., \& Rubin, J. (1996). Can strategy instruction improve listeningcomprehension? . Foreign Language Annals, (29), 331-342. Retrieved from http://dx.doi.org/10.1111/j.1944-9720.1996.tb01246.x

Ur, P. (1991). A Course in Language Teaching: Practice and Theory. Cambridge: Cambridge University Press.

Vandergrift. (2006). The Metacognitive Awareness Listening Questionnaire: Development and Validation. Language Learning 56(3), 431-462.

Vandergrift, L. (1997). The comprehension strategies of second language (French) listeners: A descriptive study. Foreign Language Annals, 30, 387-409.

Vandergrift, L., Goh, C. C. M., Mareschal, C., \& Tafaghodtari, M. H. (2006). The Metacognitive Awareness Listening Questionnaire (MALQ): Development and Validation. Language Learning, 56(3), 431-462.

Yang, C. (2009). A study of metacognitive strategies employed by English listeners. International Education Studies, 2(4), 134-13 